(2) Open Access Full Text Article

ORIGINAL RESEARCH

\title{
Exacerbation Frequency And Eosinophil Counts Among Patients With COPD Currently Prescribed Triple Therapy
}

\author{
Victoria S Benson (D) \\ Katie C Pascoe $\mathbb{I D}^{1}$ \\ James Siddall ${ }^{2}$ \\ Mark Small ${ }^{2}$ \\ Hana Müllerová (D) \\ 'GSK, Research and Development \\ Uxbridge, Uxbridge, UK; ${ }^{2}$ Adelphi Real \\ World, Adelphi Mill, Bollington, UK
}

This article was published in the following Dove Press journal: International Journal of Chronic Obstructive Pulmonary Disease

Purpose: To characterize and estimate the proportion of patients with chronic obstructive pulmonary disease (COPD) who continue to exacerbate while receiving triple therapy and further describe these patients according to blood eosinophil counts.

Methods: This was an analysis of the 2017 Adelphi Real-World Respiratory Disease Specific Programme (DSP) survey of patients with COPD from France, Germany, Italy, Spain, and the United Kingdom (UK). Demographics were assessed on the date of completion of the physician/ patient questionnaire; clinical characteristics were captured for the previous 12 months. The proportion of patients receiving triple therapy, who had experienced $\geq 2$ moderate or $\geq 1$ severe acute exacerbations of COPD (AECOPD) in the 12 months prior to index, and had blood eosinophil counts $\geq 150$ cells $/ \mu \mathrm{L}$ (T-AECOPD-EOS150) or $\geq 300$ cells $/ \mu \mathrm{L}$ (T-AECOPDEOS300), were calculated.

Results: In total, 2876 patients were included of which 762 had an eosinophil value. A higher proportion of patients in the $\geq 300$ cells/ $\mu \mathrm{L}$ eosinophil group (55.9\%) compared with $150-<300$ cells $/ \mu \mathrm{L}(48.7 \%)$ and $<150$ cells $/ \mu \mathrm{L}$ (47.1\%) groups experienced $\geq 2$ moderate and $/$ or $\geq 1$ severe AECOPD in the year prior to index. The $\geq 300$ cells $/ \mu \mathrm{L}$ eosinophil group had the lowest reported level of health-related quality of life (HRQoL). More severe disease in terms of comorbidities, lung function, healthcare resource use, and HRQoL was seen in patients with $\geq 2$ moderate or $\geq 1$ severe AECOPD in the year prior to index while receiving triple therapy, compared with patients who did not meet these criteria. In total, $10.6 \%$ and $6.2 \%$ of the COPD population, respectively, met the criteria for the T-AECOPD-EOS150 and T-AECOPD-EOS300 cohorts.

Conclusion: This analysis demonstrates that there is a subpopulation of patients with COPD who continue to experience exacerbations despite receiving triple therapy; approximately three-quarters of these had eosinophils $\geq 150$ cells $/ \mu \mathrm{L}$ and one-third had eosinophils $\geq 300$ cells $/ \mu \mathrm{L}$; these patients may benefit from eosinophil-targeted therapies.

Keywords: blood eosinophil, healthcare resource, targeted therapy, disease burden, respiratory

\section{Introduction}

Chronic obstructive pulmonary disease (COPD) is a complex and heterogeneous condition characterized by chronic airway inflammation, progressive airway obstruction, persistent respiratory symptoms, and acute exacerbations. ${ }^{1}$ In 2016 , COPD was the third leading cause of death worldwide, and the eighth greatest cause of increased health burden as measured by disability-adjusted life years. ${ }^{2,3}$
Correspondence: Victoria S Benson GSK, Stockley Park West, I-3 Ironbridge Road, Uxbridge, Middlesex UBI I IBT, UK $\mathrm{Tel}+442089903306$

Email victoria.x.tribble@gsk.com 
Much of the morbidity and mortality associated with COPD are attributed to the frequency and severity of exacerbations. ${ }^{4,5}$ A combination of an inhaled corticosteroid (ICS), a long-acting $\beta_{2}$-agonist (LABA), and a longacting muscarinic receptor antagonist (LAMA), often termed triple therapy, is recommended for patients with COPD who experience exacerbations. ${ }^{1}$ However, some patients with COPD continue to exacerbate while receiving triple therapy and may require additional treatment. ${ }^{6,7}$

To date, several studies have demonstrated that about two-thirds of patients with COPD have blood eosinophil levels $\geq 150$ cells $/ \mu \mathrm{L}$ or fluctuating above and below 150 cells $/ \mu$ L. ${ }^{8,9}$ Blood eosinophil counts may provide an indication of exacerbation risk. For example, a cross-sectional study evaluating electronic medical records and insurance claims data showed that there was a trend for higher allcause and COPD-related healthcare costs in patients with COPD who had blood eosinophil counts $\geq 150$ cells $/ \mu \mathrm{L}$ compared with patients with blood eosinophil counts $<150$ cells $/ \mu \mathrm{L}{ }^{8}$ Similar trends were also seen in the same study when using a blood eosinophil count threshold of 300 cells $/ \mu$ L. ${ }^{8}$ Other recent studies in patients with COPD have also demonstrated that blood eosinophil counts $\geq 300$ cells $/ \mu \mathrm{L}$ are associated with an increased risk of exacerbations. ${ }^{10,11}$

Patients with COPD who experience frequent exacerbations and who are receiving triple therapy have a clear unmet treatment need and may benefit from further targeted treatment. Several novel-targeted therapies currently in development reduce eosinophil counts in the blood and tissues by binding to interleukin- 5 receptors on the eosinophil surface. ${ }^{12,13}$ Currently, the relative size of the population of patients with COPD who may be eligible for further targeted treatment is poorly understood. The objectives of this analysis were to describe the characteristics, and estimate the proportion, of patients with COPD currently prescribed triple therapy who have a history of exacerbations in the last 12 months. These patients were also characterized according to blood eosinophil count $(150,150-<300$, and $\geq 300$ cells $/ \mu \mathrm{L})$.

\section{Materials And Methods Study Design}

This was an analysis of the Adelphi Real-World Respiratory Disease Specific Programme (DSP) database (GSK ID: HO-18-19326). The database contains 2017 DSP COPD survey results collected from patients with COPD from five European countries (France, Germany, Italy, Spain, UK) who had consulted with a primary care physician or specialist respiratory physician. The DSP is conducted annually and does not test any specific hypotheses but provides valuable information from real-world clinical practice. The DSP methodology has been described previously ${ }^{14}$ and is summarized in Supplementary Figure 1. In brief, physicians provided information on specific patients using physician-completed record forms (PRF), and these patients provided information on themselves and their disease at the time of consultation with the physician using patient selfcompletion questionnaires (PSC). The 2017 DSP COPD survey was conducted between February and March 2017. For each patient, the index date was the date within this period on which the PRF and PSC were completed. Relevant data were collected on this date or from recent medical history (up to 12 months prior to index date for all objectives with the exception of blood eosinophil count, which was taken from the most recent measurement available at any time in the past); no follow-up information was collected. Data were collected by local fieldwork partners, and both physician and patient data were de-identified prior to receipt by Adelphi. The survey received ethical approval from the Freiburger Ethic-Kommission International (FEKI Code 017/1014). This analysis complied with all applicable laws regarding patient privacy.

\section{Study Population}

Physician criteria for inclusion in the COPD DSP were primary care physicians or respiratory specialists with a workload minimum per week of three patients with COPD. The PRF was completed by the physician for the next five consecutive patients with physician-confirmed airflow obstruction and a diagnosis of COPD to eliminate physician sampling bias. Completion of the PSC was voluntary and was therefore not completed by every patient. Patients with a physician-confirmed current codiagnosis of asthma were excluded.

Blood eosinophil counts were reported by the physician on the index date, using the most recent available result from patient medical records. Patients were stratified by blood eosinophil count as follows: (1) none measured; (2) measured; (3) $<150$ cells $/ \mu \mathrm{L}$; (4) $\geq 150$ cells $/ \mu \mathrm{L}$; (5) 150 $<300$ cells $\mu \mathrm{L}$; and $(6) \geq 300$ cells $/ \mu \mathrm{L}$. The proportion of patients who experienced $\geq 2$ moderate or $\geq 1$ severe acute exacerbations of COPD (AECOPD) in the previous 12 months while being treated with triple therapy (defined as current prescription at index of any combination of ICS + 
LAMA + LABA to treat COPD) was also assessed. AECOPD events were collected by physicians using the PRF form using patient medical records from the previous 12 months. A moderate AECOPD was defined as management with oral corticosteroids and/or antibiotic and/or visit to emergency department (confirmed by a physician). A severe AECOPD was defined as a physician-confirmed hospital admission with an overnight stay. Two patient cohorts were defined based on a combination of the following criteria: $\geq 2$ moderate or $\geq 1$ severe AECOPD in the previous 12 months while being treated with triple therapy and a blood eosinophil count of $\geq 150$ cells $/ \mu \mathrm{L}$ (TAECOPD-EOS150 cohort) or $\geq 300$ cells $/ \mu \mathrm{L}$ (T-AECOPDEOS300).

Exact dates of AECOPDs and blood eosinophil measures were not captured in order to keep the data anonymized.

\section{Objectives}

Objectives of the study were

1. To describe the demographics and clinical characteristics of the total COPD population and the patient subgroups stratified by blood eosinophil count and exacerbation history/current therapy;

2. To describe the proportion of patients matching a COPD patient phenotype considered eligible for further targeted therapies.

Clinical characteristics recorded included comorbidities, current COPD therapy, forced expiratory volume in 1 second $\left(\mathrm{FEV}_{1}\right)$, Modified Medical Research Council Dyspnea Scale (mMRC) score, COPD Assessment Test (CAT) score, EuroQol 5 3-level questionnaire (EQ-5D3L), EuroQol visual analogue scale (EQ-VAS), and healthcare resource utilization (primary care visits, specialist care visits, and inpatient days in hospital).

\section{Statistical Analysis}

Raw counts and proportions were used for all data presented, with the exception of the proportion of patients in the population leading to the T-AECOPD-EOS150 and T-AECOPD-EOS300 cohorts. For these populations, a weight was applied to adjust for four areas of the DSP that could affect the probability of selection of each patient (frequency of physician visits, number of patients managed by the physician, specialty of each physician, and country) (Supplementary methods). All descriptive comparisons were made overall and by country, where appropriate.

Four sensitivity analyses were performed (summarized in Supplementary Figure 2). First, the characteristics of patients who completed/did not complete a PSC were compared in the total COPD population. Second, the T-AECOPD-EOS150 and T-AECOPD-EOS300 patient cohorts were limited to patients with $\geq 3$ months triple therapy use. Third, the T-AECOPDEOS150 and T-AECOPD-EOS300 patient cohorts were limited to patients who had an eosinophil value recorded within the 12 months prior to index date. Finally, the same patient cohorts were limited to patients with a record for $\geq 3$ months triple therapy use and had an eosinophil value recorded within the 12 months prior to index date.

\section{Results}

\section{Overall COPD Population Clinical And Demographic Characteristics}

A total of 2876 patients with COPD from five European countries (France, Germany, Italy, Spain, UK) were included in the analysis. Patient demographics and clinical characteristics are summarized overall and by country in Table 1. In total, $33.2 \%$ of the patients were female and the mean age for the population was 66 years. Approximately one-third of the patients were current smokers except in Italy and Spain where approximately one-quarter were. Diabetes was the most commonly reported comorbidity, ranging from $12.7 \%$ of the patients in the UK to $22.6 \%$ of the patients in Spain. The majority of patients in all countries (93.2-99.3\%) were receiving maintenance therapy for COPD. Triple therapy was the most frequently prescribed maintenance therapy in the total population (29.2\%), and in France (32.5\%), Spain (36.1\%), and the UK (41.1\%). A total of $87.2 \%$ of the population had a CAT score $\geq 10$. COPD-related healthcare resource utilization in the year prior to index date was high across all countries, with overall means of 4.8 primary care visits, 3.4 specialist care visits, and 1.8 inpatient days per patient in the previous 12 months. Overall, $45.9 \%$ of the patients experienced at least 1 moderate and/or severe exacerbations in the year prior to index.

\section{Clinical And Demographic Characteristics By Blood Eosinophil Count}

In total, 34.4\% (989/2876) of patients had at least one blood eosinophil measurement reported at the time of the survey, $77.0 \%$ (762/989) of whom had an eosinophil count (i.e., a 


\begin{tabular}{|c|c|c|c|c|c|c|c|c|c|c|c|c|}
\hline 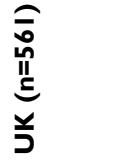 & 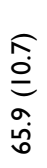 & $\stackrel{n}{\dot{q}}$ & $\begin{array}{l}\widehat{\widetilde{m}} \\
\stackrel{2}{0} \\
\stackrel{0}{0} \\
\stackrel{\sim}{0}\end{array}$ & $\hat{i}$ & $\stackrel{\infty}{\underline{I}}$ & 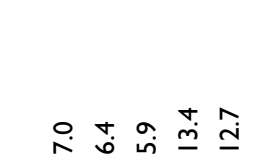 & $\stackrel{\infty}{\sigma}$ & 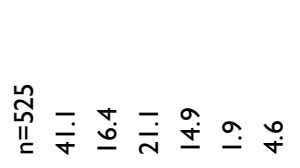 & นn & 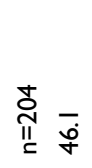 & 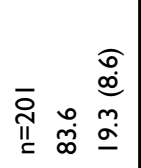 & 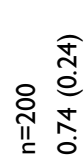 \\
\hline . & 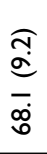 & $\stackrel{g}{\dot{d}}$ & 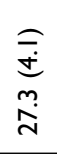 & $\tilde{\sim}$ & $\stackrel{\square}{=}$ & 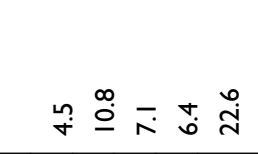 & $\stackrel{\sim}{\infty}$ & 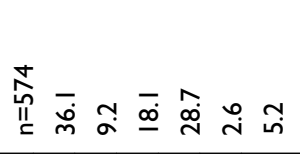 & $\stackrel{\square}{\square}$ & 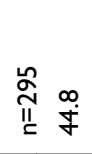 & 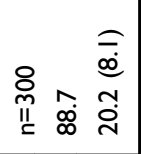 & 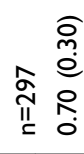 \\
\hline 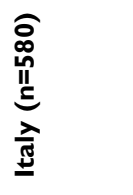 & $\begin{array}{l}\widehat{0} \\
\stackrel{0}{\dot{0}} \\
\stackrel{\circ}{0}\end{array}$ & مें & 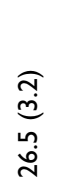 & $\stackrel{\circ}{\dot{\sim}}$ & $\stackrel{+}{\infty}$ & 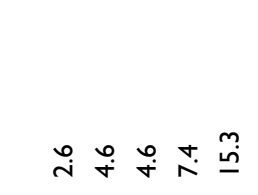 & $\stackrel{m}{\alpha}$ & 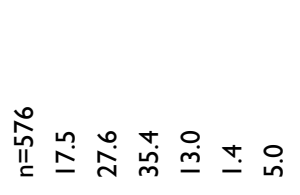 & รั & 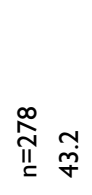 & 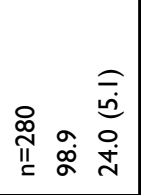 & 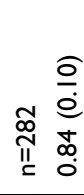 \\
\hline 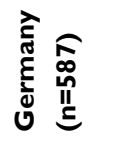 & 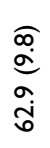 & $\frac{n}{m}$ & 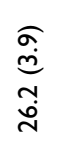 & $\overline{\dot{m}}$ & กู & 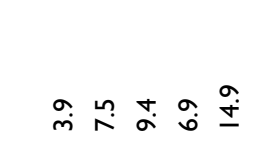 & నె & 站 욷 & $\tilde{\text { I }}$ & 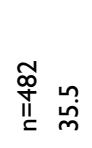 & 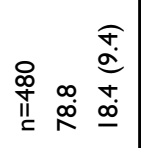 & 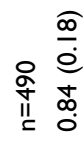 \\
\hline 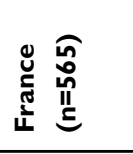 & 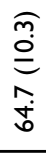 & ڤั & $\begin{array}{l}\text { F } \\
\dot{ \pm} \\
\stackrel{i}{i}\end{array}$ & 嘅 & $\stackrel{t}{\sim}$ & 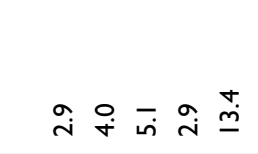 & $\bar{\infty}$ & 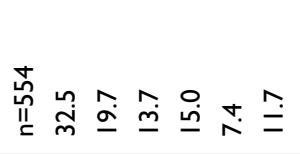 & $\hat{o}$ & $\stackrel{\infty}{\stackrel{\infty}{*}} \underset{\sim}{\pi}$ & 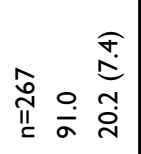 & $\underset{\substack{n \\
\text { II }}}{\stackrel{0}{\stackrel{0}{0}}}$ \\
\hline 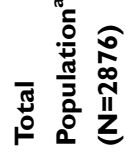 & 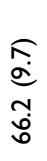 & $\stackrel{\sim}{m}$ & 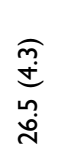 & $\stackrel{0}{0}$ & ๙ู & 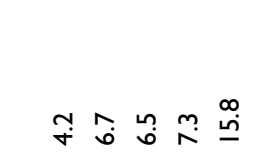 & นุ̊ & 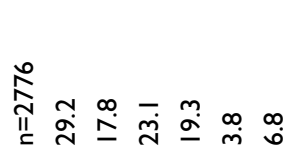 & $\stackrel{\circ}{i}$ & 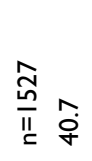 & 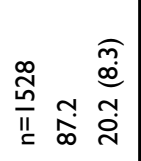 & 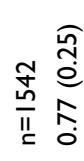 \\
\hline & 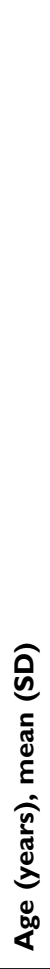 & 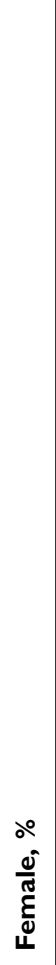 & 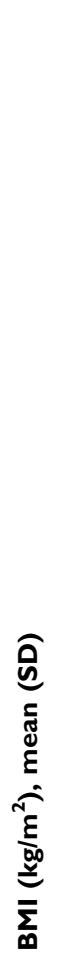 & 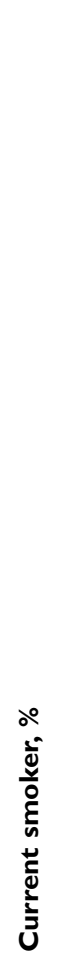 & 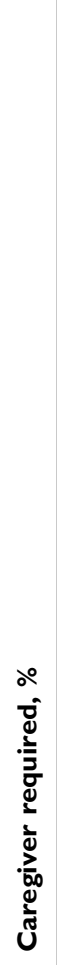 & 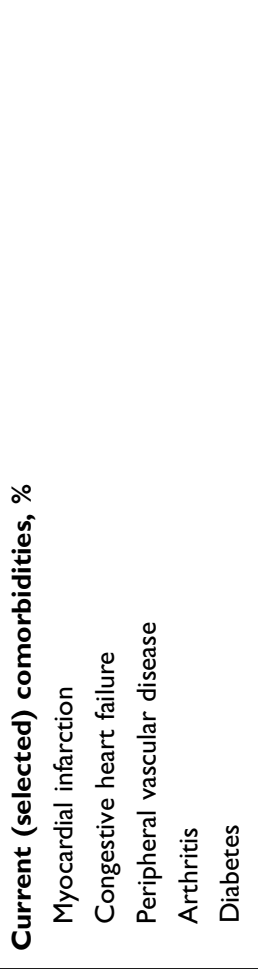 & 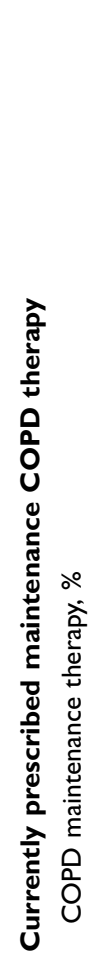 & 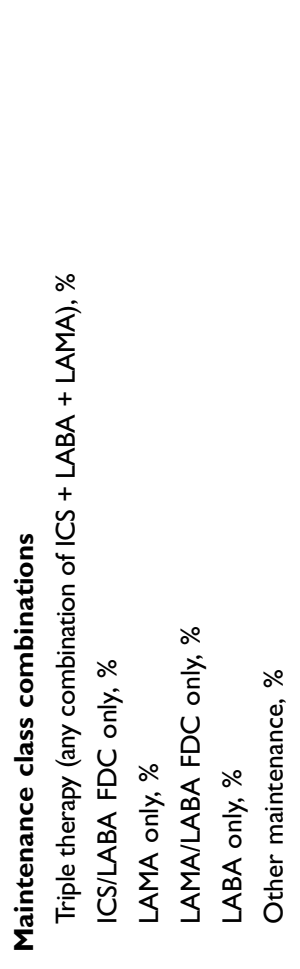 & 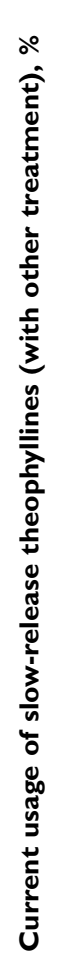 & 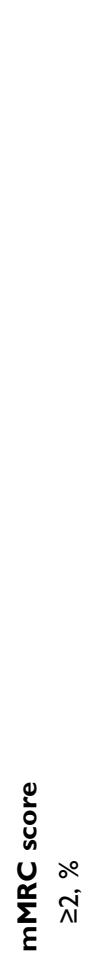 & 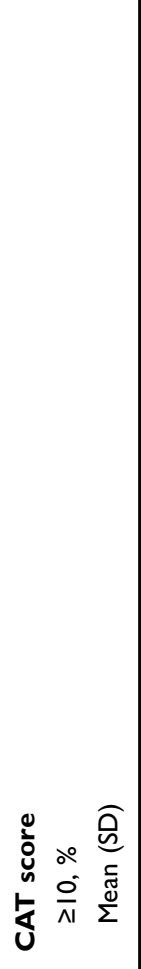 & 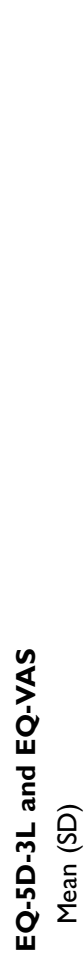 \\
\hline
\end{tabular}




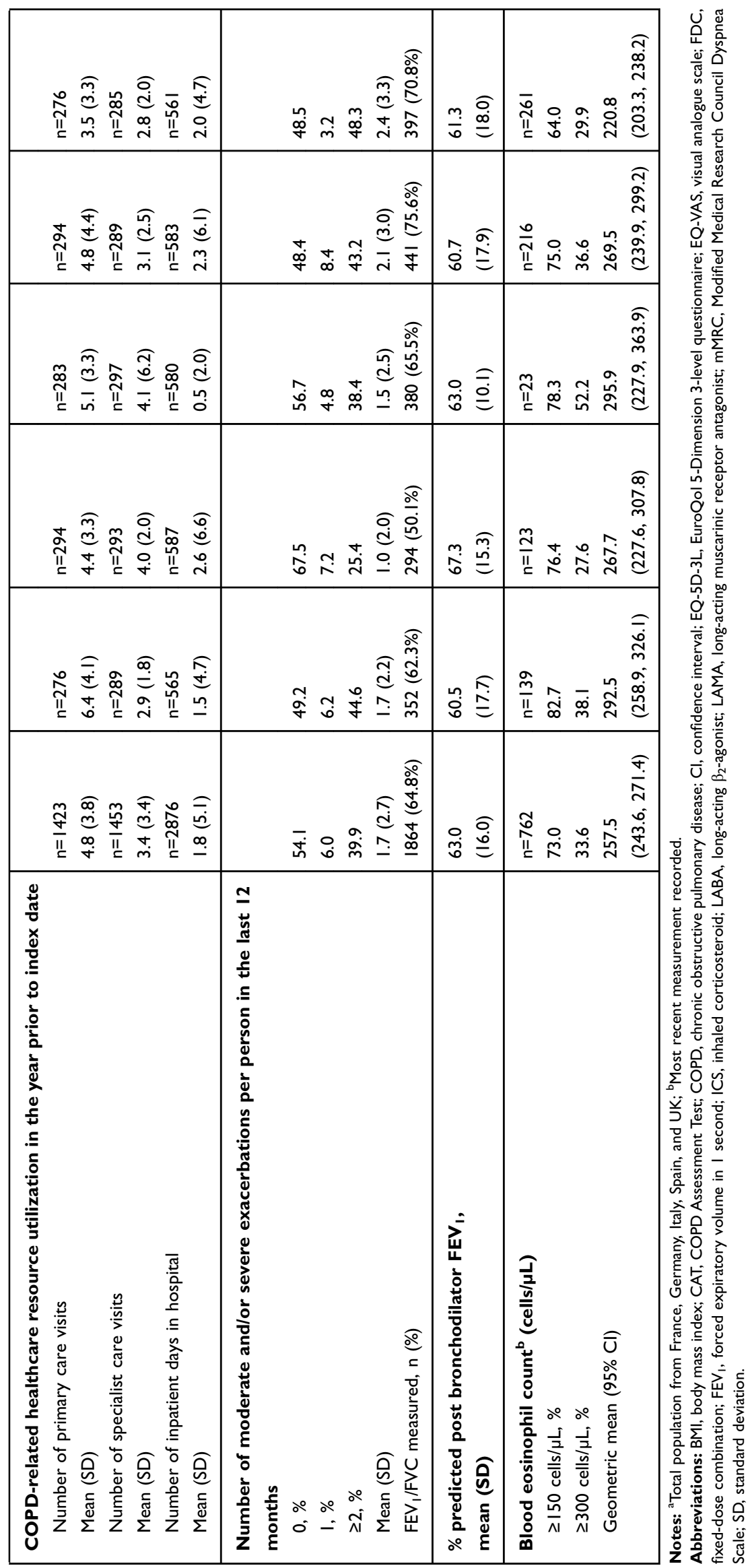


valid value) available (Table 2). Of the 762 patients for whom a blood eosinophil count was available, physicians were able to state whether this was in the last 12 months (or not) for 629 patients. Of these 629 patients, 78\% (490/629) had an eosinophil measurement within the 12 months prior to index date. Among patients with a blood eosinophil count available, $27 \%(206 / 762)$ had counts of $<150$ cells $/ \mu \mathrm{L}, 39 \%$ had counts of $150<300(300 / 762)$ cells $/ \mu \mathrm{L}$, and $34 \%(256 /$ 762) had counts of $\geq 300$ cells $/ \mu \mathrm{L}$. The overall geometric mean blood eosinophil count was 257.5 cells $/ \mu L$. Average age, BMI, smoking status, caregiver status, and COPD healthcare resource utilization were similar across the three blood eosinophil count groups. Myocardial infarction, peripheral vascular disease, and diabetes occurred most frequently in the $\geq 300$ cells $/ \mu \mathrm{L}$ group; $7.7 \%, 10.5 \%$, and $21.5 \%$, respectively, compared with $4.4 \%, 7.2 \%$ and $14.7 \%$ in the $150-<300$ cells $/ \mu \mathrm{L}$ group and $4.5 \%, 8.1 \%$, and $16.7 \%$ in the $<150$ cells $/ \mu \mathrm{L}$ group. Triple therapy was the most commonly prescribed maintenance therapy across all blood eosinophil count groups $(37.7-41.8 \%)$. The proportion of patients experiencing at least one moderate and/or severe exacerbation in the year prior to index was highest in the $\geq 300$ cells $/ \mu \mathrm{L}$ group $(62.5 \%)$ compared with the $150-<300$ cells $/ \mu \mathrm{L}$ group $(54.0 \%)$ and the $<150$ cells $/ \mu \mathrm{L}$ group $(51.5 \%)$.

\section{Clinical And Demographic Characteristics Among Triple Therapy Users With A History Of Exacerbations}

Of the 811 patients receiving triple therapy, $546(67.3 \%)$ experienced $\geq 2$ moderate or $\geq 1$ severe AECOPD within the 12 months prior to index date (Table 3). Compared with the rest of the COPD population, these patients had higher incidences of all selected comorbidities, greater use of slow-release theophyllines, higher mMRC and CAT scores, lower EQ-5D scores, indicating worse healthrelated quality of life (HRQoL), poorer lung function, as shown by lower percent predicted $\mathrm{FEV}_{1}$, and greater use of healthcare resources (primary care visits, specialist care visits, and inpatient days).

\section{T-AECOPD-EOSI50 And T-AECOPD- EOS300 Cohorts}

Overall, $10.6 \%$ of the patients met the triple therapy and AECOPD criteria and had a blood eosinophil count of $\geq 150$ cells $/ \mu \mathrm{L}$ (T-AECOPD-EOS150 cohort); and $6.2 \%$ of the patients met the triple therapy and AECOPD criteria and had a blood eosinophil count of $\geq 300$ cells $/ \mu \mathrm{L}$ (T-AECOPDEOS300 cohort). The weighted percentages of all patients with COPD who were prescribed triple therapy, had $\geq 2$ moderate or $\geq 1$ severe AECOPD, and a blood eosinophil count $\geq 150$ or $\geq 300$ cells $/ \mu \mathrm{L}$ are shown in Figure 1 and presented by country in Supplementary Table 1 .

\section{Sensitivity Analyses}

The sensitivity analysis of the characteristics for patients who completed a PSC $(n=1563)$ compared with those that did not complete the PSC $(n=1313)$ showed that the two populations were similar in terms of age, BMI, smoking status, and currently prescribed treatment (data not shown). In addition, further sensitivity analyses indicated that the weighted proportions of patients eligible for inclusion in the T-AECOPD-EOS150 and T-AECOPD-EOS300 cohorts were similar to the main analysis when the populations were limited to those treated with triple therapy for $\geq 3$ months $(9.1 \%$ and $5.8 \%$, respectively, compared with $10.6 \%$ and $6.2 \%$ for the main analysis) and to those whose blood eosinophil count had been measured within the 12 months prior to index date ( $11.1 \%$ and $6.1 \%$, respectively).

\section{Discussion}

In this analysis of survey data from 2876 patients with COPD in Europe, between 17.5\% (Italy) and 41.1\% (UK) of patients were currently prescribed triple therapy, reflecting country-specific differences in physician prescribing habits. Over half of patients currently prescribed triple therapy had $\geq 1$ severe or $\geq 2$ moderate AECOPDs in the last 12 months; $10.6 \%$ and $6.2 \%$ of the COPD population also had blood eosinophil counts $\geq 150$ cells $/ \mu \mathrm{L}$ and $\geq 300$ cells $/ \mu \mathrm{L}$, respectively. These data suggest patients with COPD who display these characteristics may benefit from eosinophil-targeted therapies.

COPD-related healthcare resource utilization in the year prior to index date was high across all countries, with overall means of 4.8 primary care visits, 3.4 specialist care visits, and 1.8 inpatient days per patient. These figures are similar to those reported in other studies. ${ }^{15,16}$ For example, the rate of 4.8 primary care visits per patient in the 12 months prior to index shown in the current analysis was comparable to the mean of 3.6 primary care visits within a 12 -month period shown by Ding et al, ${ }^{16}$ which is based on a previous Adelphi DSP survey conducted in 2013. It is worth noting that patients enrolled in the Adelphi DSP annual survey are different each year; therefore, it is unlikely that those who participated in the 2013 


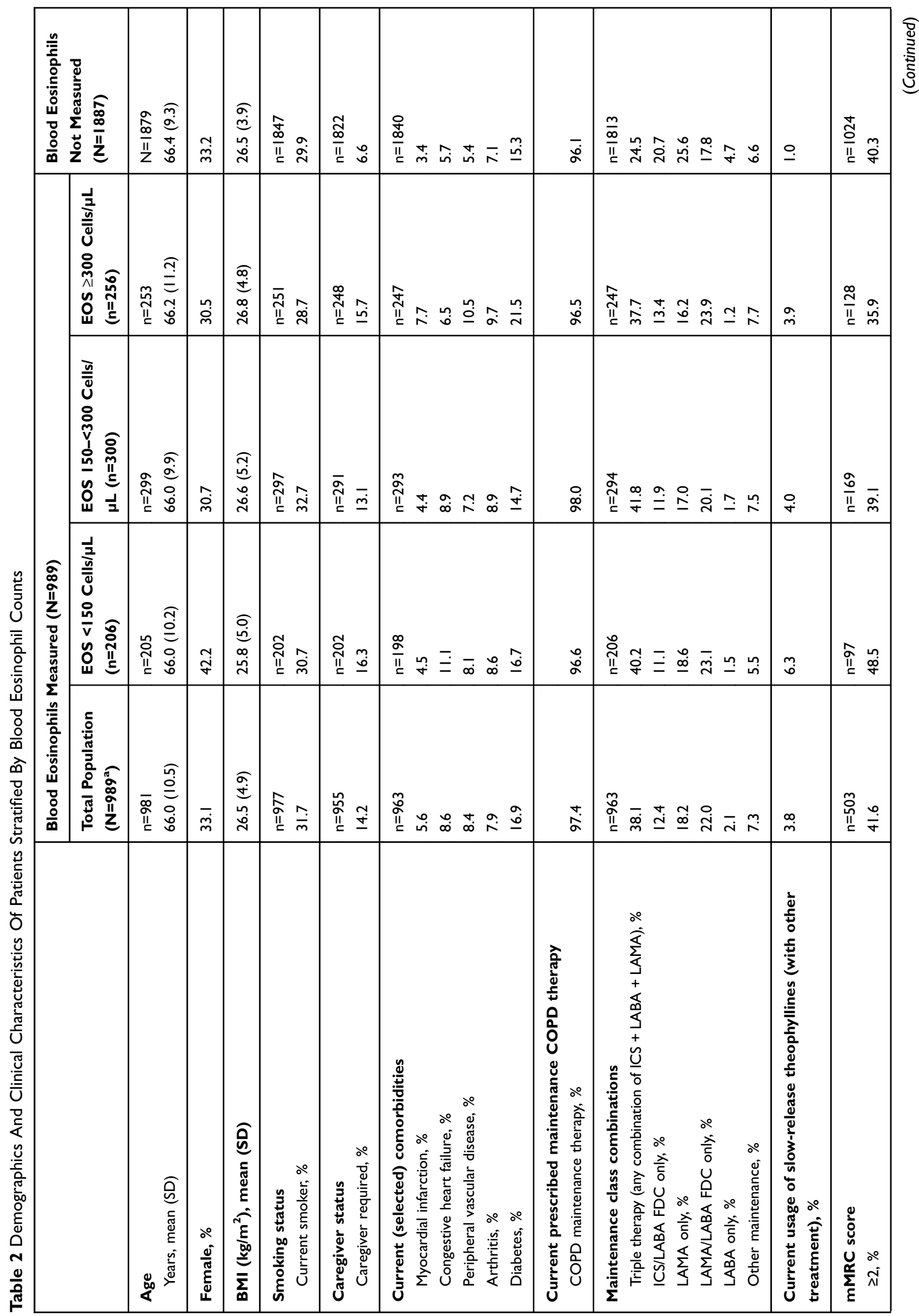




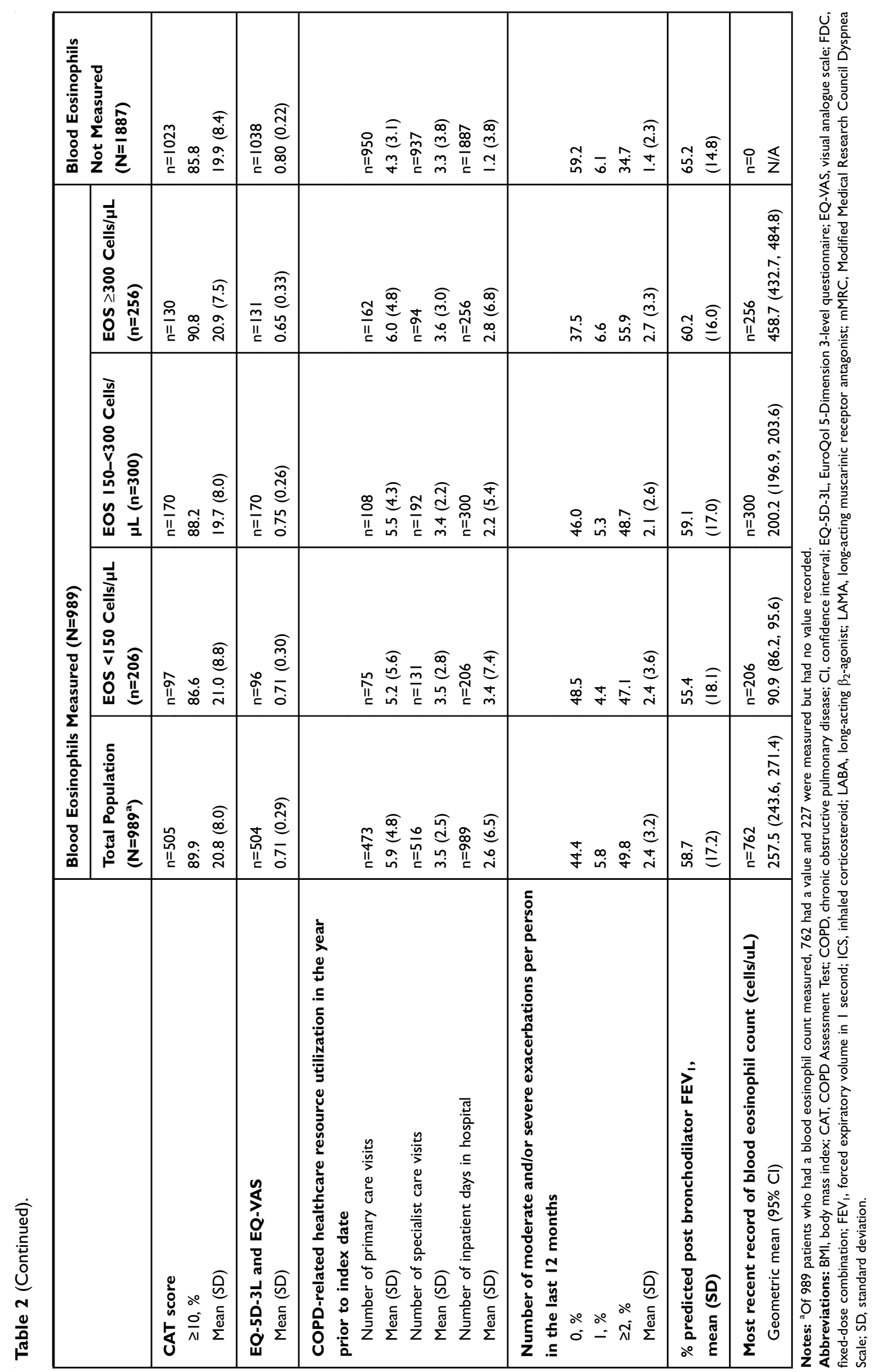


Table 3 Demographics And Clinical Characteristics Of Patients With COPD By Exacerbations History/Current Therapy

\begin{tabular}{|c|c|c|}
\hline & $\begin{array}{l}\text { Patients With COPD With } \geq 2 \\
\text { Moderate or } \geq 1 \text { Severe AECOPD } \\
\text { Within The Last } 12 \text { Months And } \\
\text { Currently Being Treated With Triple } \\
\text { Therapy ( } n=546)\end{array}$ & $\begin{array}{l}\text { Total COPD } \\
\text { Population }(n=2330)\end{array}$ \\
\hline Age & $n=540$ & $n=2320$ \\
\hline Years, mean (SD) & $68.7(9.4)$ & $65.7(9.7)$ \\
\hline Female, \% & 29.1 & 34.1 \\
\hline BMI $\left(\mathrm{kg} / \mathrm{m}^{2}\right)$, mean (SD) & $n=50726.9(4.8)$ & $n=224026.4(4.1)$ \\
\hline Smoking status & $n=536$ & $n=2228$ \\
\hline Current smoker, \% & 29.3 & 30.9 \\
\hline Caregiver status & $n=534$ & $n=2243$ \\
\hline Caregiver required, \% & 19.5 & 6.8 \\
\hline Current (selected) comorbidities & $n=540$ & $n=2263$ \\
\hline Myocardial infarction, \% & 6.7 & 3.6 \\
\hline Congestive heart failure, $\%$ & 13.9 & 5.0 \\
\hline Peripheral vascular disease, \% & 9.3 & 5.8 \\
\hline Arthritis, \% & 7.2 & 7.4 \\
\hline Diabetes, \% & 22.0 & 14.4 \\
\hline \multicolumn{3}{|l|}{ Current prescribed treatment } \\
\hline COPD maintenance therapy, \% & 100 & 95.7 \\
\hline Maintenance class combinations & $n=546$ & $n=2230$ \\
\hline Triple therapy (any combination of ICS + LABA + LAMA), \% & 100 & 11.9 \\
\hline ICS/LABA FDC only, \% & 0 & 22.2 \\
\hline LAMA only, \% & 0 & 28.7 \\
\hline LAMA/LABA FDC only, \% & 0 & 24.0 \\
\hline LABA only, \% & 0 & 4.8 \\
\hline Other maintenance, \% & 0 & 8.5 \\
\hline Current usage of slow-release theophyllines (with other treatment), \% & 6.2 & 1.0 \\
\hline mMRC score & $n=256$ & $n=|27|$ \\
\hline$\geq 2, \%$ & 69.1 & 35.0 \\
\hline CAT score & $n=263$ & $n=1265$ \\
\hline$\geq 10, \%$ & 95.4 & 85.5 \\
\hline Mean (SD) & $24.9(7.3)$ & $19.2(8.1)$ \\
\hline EQ-5D-3L and EQ-VAS & $n=260$ & $n=1282$ \\
\hline Mean (SD) & $0.63(0.32)$ & $0.80(0.22)$ \\
\hline \multicolumn{3}{|l|}{$\begin{array}{l}\text { COPD-related healthcare resource utilization in the year prior to index } \\
\text { date }\end{array}$} \\
\hline Number of primary care visits & $n=223$ & $n=1200$ \\
\hline Mean (SD) & $6.3(4.5)$ & $4.6(3.6)$ \\
\hline Number of specialist care visits & $n=323$ & $n=1130$ \\
\hline Mean (SD) & $3.8(2.3)$ & $3.2(3.7)$ \\
\hline Number of inpatient days in hospital & $n=546$ & $n=2330$ \\
\hline Mean (SD) & $3.1(7.2)$ & $0.9(2.9)$ \\
\hline $\begin{array}{l}\% \text { predicted post bronchodilator } \mathrm{FEV}_{\mathrm{l}} \text {, } \\
\text { mean (SD) }\end{array}$ & $\begin{array}{l}n=276 \\
53.5(16.3)\end{array}$ & $\begin{array}{l}n=1038 \\
65.6(14.9)\end{array}$ \\
\hline
\end{tabular}


Table 3 (Continued).

\begin{tabular}{|c|c|c|}
\hline & $\begin{array}{l}\text { Patients With COPD With } \geq 2 \\
\text { Moderate or } \geq 1 \text { Severe AECOPD } \\
\text { Within The Last I } 2 \text { Months And } \\
\text { Currently Being Treated With Triple } \\
\text { Therapy }(n=546)\end{array}$ & $\begin{array}{l}\text { Total COPD } \\
\text { Population }(n=2330)\end{array}$ \\
\hline Most recent record of blood eosinophil count (cells/uL) & $n=209$ & $n=553$ \\
\hline$\geq 150$ cells $/ \mu \mathrm{L}, \%$ & 73.7 & 72.7 \\
\hline$\geq 300$ cells $/ \mu \mathrm{L}, \%$ & 33.5 & 33.6 \\
\hline Geometric mean $(95 \% \mathrm{Cl})$ & $243.6(221.4,265.9)$ & $262.8(245.6,280.0)$ \\
\hline
\end{tabular}

Abbreviations: BMI, body mass index; CAT, COPD Assessment Test; COPD, chronic obstructive pulmonary disease; Cl, confidence interval; EQ-5D-3L, EuroQol 5Dimension 3-level questionnaire; EQ-VAS, visual analogue scale; FDC, fixed-dose combination; $\mathrm{FEV}_{1}$, forced expiratory volume in I second; ICS, inhaled corticosteroid; LABA, long-acting $\beta_{2}$-agonist; LAMA, long-acting muscarinic receptor antagonist; mMRC, Modified Medical Research Council Dyspnea Scale; SD, standard deviation.

survey also took part in the 2017 survey. In addition, a COPD cohort study using electronic medical records identified from the Clinical Practice Research Datalink (CPRD) reported an overall mean value of 12.3 GP practice medical visits over 12 months in the UK. However, it is likely that this figure is higher than that seen in our study because it includes all-cause GP consultations, not those exclusively due to COPD. ${ }^{15}$

The current analysis also determined demographic and clinical characteristics in patients stratified by the presence/ absence of a blood eosinophil count measurement, and further by blood eosinophil count, where available. Blood and sputum eosinophil counts have been shown to be associated with disease burden in patients with COPD and may act as a surrogate biomarker to predict clinical outcomes. ${ }^{8,11,17-19}$ The measurement of blood eosinophil counts is practical and

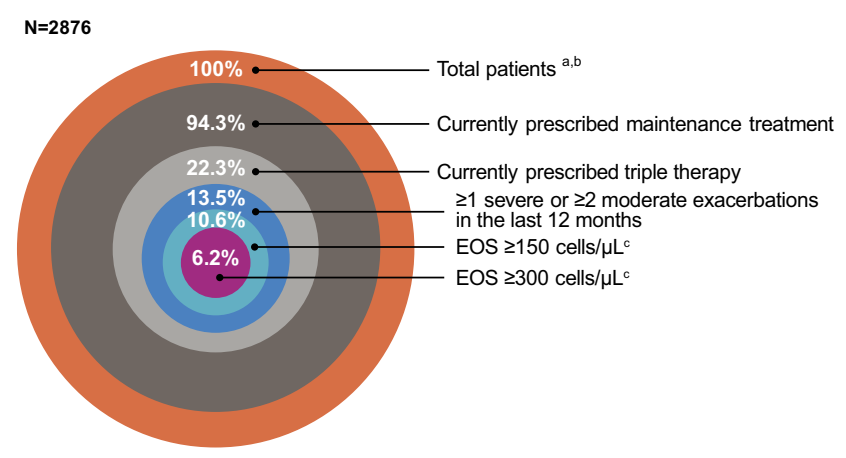

Figure I Proportion of patients from the total diagnosed COPD sample (weighted absolute percentages) who were prescribed triple therapy, had $\geq 2$ moderate or $\geq 1$

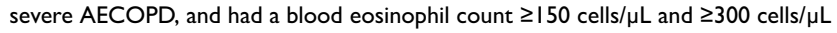
in the five European countries studied.

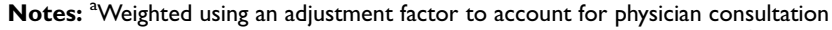
rates, and consultation workload, physician specialty, and country size; 'brance,

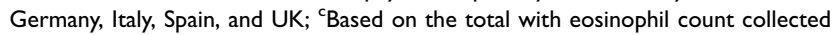
as part of routine clinical care $(n=762)$.

Abbreviations: AECOPD, acute exacerbations of COPD; COPD, chronic obstructive pulmonary disease; EOS, blood eosinophil count. the collection of blood samples is much simpler than collecting sputum samples, which requires specialist training. ${ }^{20}$ However, the measurement of blood eosinophil counts in patients with COPD is only now becoming more established in clinical practice. This is demonstrated by the fact that only $34.4 \%$ of the patients in the current analysis had a blood eosinophil measurement recorded in the patient record form, although it is important to note that this is an increase from $26.0 \%$ of the patients who had an eosinophil measurement available in the 2016 Adelphi Respiratory DSP (data not published). In general, the group of patients with a blood eosinophil count measurement available tended to present with a severe exacerbation history and multiple comorbidities. This may indicate that there is a greater likelihood of blood eosinophil count being measured if a patient has multiple morbidities.

Of those patients who did have an eosinophil count available, $27 \%$ had counts of $<150$ cells $/ \mu \mathrm{L}, 39 \%$ had measurements of $150-300$ cells $/ \mu \mathrm{L}$, and $34 \%$ had eosinophil counts $\geq 300$ cells $/ \mu \mathrm{L}$. Our analysis supported previous findings demonstrating higher symptom burden in terms of exacerbations experienced in the 12 months prior to index date in patients with eosinophil counts $\geq 300$ cells $/ \mu \mathrm{L}$ compared with those in the two lower eosinophil count groups. ${ }^{8}$ Our analysis also demonstrated that the $\geq 300$ cells $/ \mu \mathrm{L}$ eosinophil group had the lowest reported HRQoL. Within the COPD population, both blood eosinophil counts of $\geq 150$ cells $/ \mu \mathrm{L}$ and higher rates of exacerbations have been associated with significantly higher all-cause and COPD-related healthcare costs, ${ }^{8}$ while COPD-specific mortality and COPD exacerbations have been linked to higher eosinophil counts. ${ }^{5,11,17,19}$ Indeed, our own analysis highlighted more severe disease in terms of comorbidities, mMRC and CAT scores, and use of healthcare resources, in patients who experienced $\geq 2$ moderate or $\geq 1$ 
severe AECOPD in the 12 months prior to index date, compared with patients who did not experience this frequency of exacerbations in the same period. Together, these results demonstrate a higher clinical disease burden in patients with higher blood eosinophil counts and/or frequent COPD exacerbations ( $\geq 2$ moderate or $\geq 1$ severe AECOPD).

The guidance for patients with COPD who continue to experience exacerbations is to prescribe inhaled triple therapy in an attempt to control these episodic deteriorations of COPD. ${ }^{1}$ However, our analysis found that a small proportion $(10.6 \%)$ of the COPD population continued to experience exacerbations while receiving triple therapy and also had blood eosinophil counts $\geq 150$ cells/ $\mu \mathrm{L}$ (T-AECOPD-EOS150 cohort), which is consistent with findings from another study. ${ }^{21}$ These figures were also similar in sensitivity analyses that selected patients who had $\geq 3$ months of triple therapy, and in patients who had a blood eosinophil count measurement within 12 months of the index date. These results highlight the need for targeted novel treatment strategies for patients with COPD.

The current analysis has several limitations. First, patients participating in the DSP survey may not reflect the general COPD population, as those who have more severe disease are likely to have more frequent physician visits and may be more likely to be sampled than those who do not consult their physician as often. Second, the real-world nature of the DSP means that data are collected as part of routine clinical practice. As a result, the diagnosis of COPD may not have involved the use of spirometry, which is recommended as the gold standard for COPD diagnosis, ${ }^{1}$ as spirometry values may not necessarily have been known to the physician completing the patient record form.

\section{Conclusion}

This analysis indicates that it is possible to define a subpopulation of patients with high disease burden who continue to experience exacerbations despite receiving triple therapy during routine clinical practice and that these patients may benefit from eosinophil-targeted therapies. Further research concerning the role of eosinophilic inflammation in COPD patients and treatment response, in addition to characterization of this patient population, may also help aid clinical decision-making.

\section{Abbreviations}

AECOPD, acute exacerbations of COPD; CAT, COPD Assessment Test; COPD, chronic obstructive pulmonary disease; DSP, Disease Specific Programme; EQ-5D-3L, EuroQol 5 3-level questionnaire; EQ-VAS, EuroQol visual analogue scale; $\mathrm{FEV}_{1}$, forced expiratory volume in 1 second; HRQoL, health-related quality of life; ICS, inhaled corticosteroid; LABA, long-acting $\beta_{2}$-agonist; LAMA, long-acting muscarinic receptor antagonist; mMRC, Modified Medical Research Council Dyspnea Scale; PRF, physician-completed record forms; PSC, patient self-completion questionnaires; T-AECOPD-EOS150, patients receiving triple therapy with AECOPD in the 12 months prior to the index date with blood eosinophils counts $\geq 150$ cells $/ \mu \mathrm{L}$; T-AECOPD-EOS300, patients receiving triple therapy with AECOPD in the 12 months prior to the index date with blood eosinophils counts $\geq 150$ cells $/ \mu \mathrm{L}$.

\section{Ethics Approval And Informed Consent}

The Adelphi survey received ethical approval from the Freiburger Ethic-Kommission International (FEKI Code 017/1014). This analysis complied with all applicable laws regarding patient privacy.

\section{Data Availability}

GSK makes available anonymized individual participant data and associated documents from interventional clinical studies which evaluate medicines, upon approval of proposals submitted to www.clinicalstudydatarequest.com. To access data for other types of GSK sponsored research, for study documents without patient-level data and for clinical studies not listed, please submit an enquiry via the website. The data that support the findings of this study are available from Adelphi Real World where restrictions apply to the availability of these data, which were used under license for the current study, and so are not publicly available. Data are, however, available from the authors upon reasonable request and with permission of Adelphi Real World.

\section{Acknowledgments}

This analysis was funded by GSK (GSK ID: HO-18-19326). Editorial support (in the form of writing assistance, including development of the initial draft based on author direction, assembling tables and figures, collating authors' comments, grammatical editing, and referencing) was provided by Susan Parker PhD, CMPP, and Kerry Knight, PhD, at Fishawack Indicia Ltd, UK, and was funded by GSK.

\section{Author Contributions}

VB, HM, KP, JS, and MS all contributed to the conception and design of the analysis. JS and MS were involved in the 
acquisition of the data during the analysis. All authors contributed to the analysis and interpretation of the data. All authors critically revised the manuscript for intellectual content, gave final approval of the version to be published, and agreed to be accountable for all aspects of the work.

\section{Funding}

This analysis was funded by GSK (HO-18-19326).

\section{Disclosure}

VB is an employee at GSK and holds stocks/shares. KP and HM are former employees of GSK and hold stocks/shares. KP is currently employed at Janssen, High Wycombe, UK. HM is currently employed by AstraZeneca, Cambridge, UK. MS and JS are full-time employees at Adelphi Real World, which received funding from GSK to perform this analysis. Employees of Adelphi Real World were not paid for manuscript development. The authors report no other conflicts of interest in this work.

\section{References}

1. Global Initiative for Chronic Obstructive Lung Disease. Global strategy for the diagnosis, management and prevention of chronic obstructive pulmonary disease. 2018. Available from: https://goldcopd.org/ wp-content/uploads/2017/11/GOLD-2018-v6.0-FINAL-revised-20Nov_WMS.pdf. Accessed November 19, 2019.

2. World Health Organization. The top 10 causes of death. 2018. Available from: http://www.who.int/en/news-room/fact-sheets/detail/ the-top-10-causes-of-death. Accessed November 19, 2019.

3. GBD 2016 DALYs and Hale Collaborators. Global, regional, and national disability-adjusted life-years (DALYs) for 333 diseases and injuries and healthy life expectancy (HALE) for 195 countries and territories, 1990-2016: a systematic analysis for the Global Burden of Disease Study 2016. Lancet. 2017;390(10100):1260-1344. doi:10.1016/S0140-6736(17)32130-X

4. Seemungal TA, Donaldson GC, Paul EA, Bestall JC, Jeffries DJ, Wedzicha JA. Effect of exacerbation on quality of life in patients with chronic obstructive pulmonary disease. Am J Respir Crit Care Med. 1998;157(5 Pt 1):1418-1422. doi:10.1164/ajrccm.157.5.9709032

5. Soler-Cataluna JJ, Martinez-Garcia MA, Roman Sanchez P, Salcedo E, Navarro M, Ochando R. Severe acute exacerbations and mortality in patients with chronic obstructive pulmonary disease. Thorax. 2005;60 (11):925-931. doi:10.1136/thx.2005.040527

6. Müllerová H, Maskell J, Meeraus WH, Galkin D, Albers FC, Gait C. Characterization of COPD patients treated with inhaled triple therapy containing Inhaled Corticosteroids [ICS], Long-Acting Beta2-Agonists [LABA], and Long-Acting Muscarinic Antagonists [LAMA] in the UK. Am J Respir Crit Care Med. 2017;195:A4986.
7. Vestbo J, Papi A, Corradi M, et al. Single inhaler extrafine triple therapy versus long-acting muscarinic antagonist therapy for chronic obstructive pulmonary disease (TRINITY): a double-blind, parallel group, randomised controlled trial. Lancet. 2017;389(10082):19191929. doi:10.1016/S0140-6736(17)30188-5

8. Ortega H, Llanos JP, Lafeuille MH, et al. Burden of disease associated with a COPD eosinophilic phenotype. Int $J$ Chron Obstruct Pulmon Dis. 2018;13:2425-2433. doi:10.2147/COPD.S170995

9. Landis S, Suruki R, Maskell J, Bonar K, Hilton E, Compton C. Demographic and clinical characteristics of COPD patients at different blood eosinophil levels in the UK clinical practice research datalink. COPD. 2018;15(2):177-184. doi:10.1080/15412555.2018.1441275

10. Zeiger RS, Tran TN, Butler RK, et al. Relationship of blood eosinophil count to exacerbations in chronic obstructive pulmonary disease. J Allergy Clin Immunol Pract. 2018;6(3):944-954 e945. doi:10.1016/ j.jaip.2017.10.004

11. Vedel-Krogh S, Nielsen SF, Lange P, Vestbo J, Nordestgaard BG. Blood eosinophils and exacerbations in chronic obstructive pulmonary disease. The copenhagen general population study. Am J Respir Crit Care Med. 2016;193(9):965-974. doi:10.1164/rccm.201509-18690C

12. Barjaktarevic IZ, Arredondo AF, Cooper CB. Positioning new pharmacotherapies for COPD. Int $J$ Chron Obstruct Pulmon Dis. 2015;10:1427-1442. doi:10.2147/COPD.S83758

13. Busse W, Chupp G, Nagase H, et al. Anti-IL-5 treatments in patients with severe asthma by blood eosinophil thresholds: indirect treatment comparison. J Allergy Clin Immunol. 2018. doi:10.1016/j.jaci.2018.08.031

14. Anderson P, Benford M, Harris N, Karavali M, Piercy J. Real-world physician and patient behaviour across countries: disease-specific programmes - a means to understand. Curr Med Res Opin. 2008;24 (11):3063-3072. doi:10.1185/03007990802457040

15. Müllerová H, Lu C, Li H, Tabberer M. Prevalence and burden of breathlessness in patients with chronic obstructive pulmonary disease managed in primary care. PLoS One. 2014;9(1):e85540. doi:10.1371/ journal.pone. 0085540

16. Ding B, Small M, Bergstrom G, Holmgren U. COPD symptom burden: impact on health care resource utilization, and work and activity impairment. Int $J$ Chron Obstruct Pulmon Dis. 2017;12:677-689. doi:10.2147/COPD.S123896

17. Pavord ID, Chanez P, Criner GJ, et al. Mepolizumab for eosinophilic chronic obstructive pulmonary disease. N Engl J Med. 2017;377 (17):1613-1629. doi:10.1056/NEJMoa1708208

18. Bafadhel M, Pavord ID, Russell REK. Eosinophils in COPD: just another biomarker? Lancet Respir Med. 2017;5(9):747-759. doi:10.1016/S2213-2600(17)30217-5

19. Hospers JJ, Schouten JP, Weiss ST, Rijcken B, Postma DS. Asthma attacks with eosinophilia predict mortality from chronic obstructive pulmonary disease in a general population sample. Am J Respir Crit Care Med. 1999;160(6):1869-1874. doi:10.1164/ ajrccm.160.6.9811041

20. Weiszhar ZH, Horvath I. Induced sputum analysis: step by step. Breathe. 2013;9:300-306. doi:10.1183/20734735.042912

21. Müllerová H, Galkin D, Albers FC, Landis SH, Meeraus WH. Characteristics and outcomes of COPD patients with blood eosinophils $\geq 150$ cells $/ \mu \mathrm{L}$ who continue to exacerbate whilst treated with multiple inhaler triple therapy. Am J Respir Crit Care Med. 2018;197:A3137. 


\section{Publish your work in this journal}

The International Journal of COPD is an international, peer-reviewed journal of therapeutics and pharmacology focusing on concise rapid reporting of clinical studies and reviews in COPD. Special focus is given to the pathophysiological processes underlying the disease, intervention programs, patient focused education, and self management

protocols. This journal is indexed on PubMed Central, MedLine and CAS. The manuscript management system is completely online and includes a very quick and fair peer-review system, which is all easy to use. Visit http://www.dovepress.com/testimonials.php to read real quotes from published authors.

Submit your manuscript here: https://www.dovepress.com/international-journal-of-chronic-obstructive-pulmonary-disease-journal 